\title{
Evidence of the Covid-19 Pandemic Impact on Firm Performance and Financial Statement Fraudulence of Firms Listed on Stock Markets in Vietnam
}

\author{
Vu Huu DUC ${ }^{1}$, Hoang Trong HIEP ${ }^{2 *}$ and Le Vu Ngoc THANH \\ ${ }^{1}$ Ho Chi Minh city Open University, Ho Chi Minh city, Vietnam \\ ${ }^{2,3}$ School of Accounting, UEH, Ho Chi Minh city, Vietnam \\ *Corresponding author: Hoangtronghiep@ueh.edu.vn
}

\begin{abstract}
Past studies on the topic were conducted in normal economical contexts, which have not been affected by a disastrous pandemic like the Covid-19, which has been freezing the economy, breaking global supply chains and productions. Under the special circumstance, the operating results of many businesses are affected, so businesses can cheat on financial statements to create an unreal sound financial position to retain investors; or it is possible that the enterprise creates a worse financial situation, blaming external circumstances to create a reserve fund to compensate for the operation of the following years. Covid-19, therefore, is an opportunity to provide evidence of the pandemic's impact on financial reporting fraud in relation to business characteristics.
\end{abstract}

\section{Research purpose:}

This research examines the impact of the pandemic on businesses'financial performance such as revenue growth, operating cash flows as well as on the financial statement fraud.

\section{Research motivation:}

The Covid-19 pandemic has affected the lives and economies of the whole world. Social distancing, supply chain and production disruptions make it difficult for listed companies, so managers may have to commit frauds on financial statements to achieve business targets, personal goals of managers as well as to reassure investors.

Research design, approach, and method:

This study uses the financial statements of companies listed on Vietnam's stock markets for the 2014-2020 periods. The firm-year sample are then divided into fraud and non-fraud sample based on the threshold suggested by Beneish (1999) and Roxas (2011). Statistical testing is performed using $R$ software to test the difference, model testing for panel data, logit regression and test the sensitivity of the model.

\section{Main findings:}

This research finds that Covid-19 has not affected businesses' financial performance and that Covid-19 reduces the fraudulent behavior on financial statements.

\section{Practical/managerial implications:}

This research results set light on the impacts of a particular pandemic on firm performance. The market participants and professional accountants might use this research useful in assessing risks of material misstatement on information provided by enterprises.

Keywords: Adjusted M-score model, Covid-19 pandemic, financial statements fraud

\section{INTRODUCTION}

Financial statements are a product of an enterprise to provide information about the financial position, financial performance, cash flows and related notes of the enterprise to the outside users. According to the conceptual framework of the International Accounting Standards Board (2018), the users of financial statements are current and potential investors, creditors, and lenders. These parties will use financial statements for their economic decision-making, such as lending or investing in businesses.

Management is a type of labor but with a special role coordinating the activities of business inputs and carrying out the contracts agreed among those inputs. Therefore, there exists a contract between firms' 
management (agent) with firms' shareholder (principle). When that special labor contract is not efficient, management is in an advantage to maximize his benefits, either to enjoy the contractual rewards or avoid the risks, instead of maximizing firm value (Jensen \& Meckling, 1976) as management have more internal information and power to override the control of the business. On the other hand, shareholders always try to minimize this tendency by using many internal and external control mechanism such as building strong governance board and internal audit committee, contracting competent external professional service. Besides, applying the signal theory of Spence (1973) to the field of financial statements, due to asymmetry of information between managers and outsiders, managers need to provide information (signals) to the market for external parties to evaluate and make investment decisions. Financial statements are the signals that businesses provide to market participants. However, under the pressure of the business environment, managers are more likely to give "false signals" when financial statement fraud is possible (Littler, 2006). Especially, for listed companies, the information on financial statements has a clear impact on stock prices (Ahmed \& Safdar, 2018)

Financial statement fraud is the act of manipulating the financial statements to produce a business result and financial position in a desired direction to achieve management's purposes. The ultimate purpose of financial statement fraud is to affect a company's profits, assets and liabilities via the abuses of accounting policies or phony entries.

Previous studies result that corporate and board characteristics as well as audit firms have an impact on earnings management behavior (David Huguet and Juan L. Gandía (2016), Simon Cadez (2017), Aloke Ghosh et al (2010). However, these studies were conducted in normal economical contexts, which have not been affected by a disastrous pandemic like the Covid-19, which has been freezing the economy, breaking global supply chains and productions. In this special context, the operating results of many businesses are affected, so businesses can cheat on financial statements to create an unreal sound financial position to retain investors; Or it is possible that the enterprise creates a worse financial situation, blaming external circumstances to create a reserve fund to compensate for the operation of the following years. So, will Covid 19 affect businesses as well as the fraudulent behavior on the financial statements of listed companies? Covid 19 is also an opportunity to provide evidence of the pandemic's impact on financial reporting fraud in relation to business characteristics.

This study measures the impact of company characteristics such as company size, growth, operating cash flow, company age, listing time, solvency, and leverage on financial statements fraud in the years before and after Covid 19 of companies listed on Vietnam stock markets in from 2015 to 2020.

\section{LITERATURE REVIEW AND HYPOTHESIS DEVELOPMENT}

\subsection{Literature review \\ Background of Covid-19 and enterprises}

The Covid 19 pandemic first appeared in December 2019 in Wuhan - China, then spread to many countries around the world, including Vietnam. According to the Covid-19 acute respiratory infection website, by the beginning of August 2021, the number of infections in the world has nearly reached 200 million and the number of deaths is more than 4 million (Archived: WHO Timeline - COVID-19, 2021). Vietnam has experienced four waves of disease. In 2020, two outbreaks occurred with a total of 1,474 infections and 35 deaths. In 2021, the epidemic becomes more complicated. Currently, Vietnam is experiencing the 4th wave of the pandemic with the number of infections as of the beginning of August 2021 has exceeded 150,000 people with more than 1,100 deaths

Covid-19 has severely affected the level of economic activity and the market indexes and stocks' price due to social distancing, monetary policy decisions and international travel restrictions (Ozili, Peterson and Arun, 2020). In Vietnam, according to the website of the Ministry of Industry and Trade, the total retail sales of consumer goods and services in July 2021 is estimated at VND 339.4 trillion, decreasing by $8.3 \%$ from the previous month and by $19.8 \%$ over the same period last year. Of which, passenger transport in July 2021 was estimated at 146.3 million passengers, decreasing by $50.4 \%$ over the same period last year. Cargo transportation was estimated at 111.5 million tons of transported goods, decreasing by $24.3 \%$ over the same period last year. Retail sales of goods reached VND 291.8 trillion, decreasing by $5.5 \%$ and $11.4 \%$; revenue from accommodation and food services reached VND 21.2 trillion, decreasing by $22.4 \%$ and down $53.8 \%$; tourism revenue reached 133 billion, decreasing by $4.8 \%$ and $92.6 \%$; other service revenue reached 26.3 trillion dong, decreasing by $22.4 \%$ and $43 \%$. The decrease in revenue of all categories shows that Covid 19 can affect the operating cash flows and business activities as well as the growth of businesses (MOIT, 2021)

Small and medium-sized listed companies are most affected by this pandemic (Rababah et al., 2020). Besides, banks, insurance enterprises, governmental investments, financial markets are predicted to be significantly impacted (Goodell, 2020). Covid 19 will lead to a change in capital structure, firms will use less financial leverage as there will be a significant increase in the cost of equity on a global scale.

Financial reporting and fraud on financial statements A set of financial statements is a structured presentation of an entity's economic resources and claims, and their changes for a financial period. The objective of financial statements is to provide information about an entity's financial position, financial performance, cash flows, and changes in equity that is useful to a wide range of 
users in making economic decisions. Financial statements also show the results of management's handling of delegated resources. A set of financial statements include statement of financial position; statement of comprehensive income; statement of cash flows; statement of changes in equity; and related notes. To be issued for general purpose, financial statement must include relevant-to-intended-users information and be fairly presented. Moreover, financial information quality is enhanced if it is comparable, verifiable, understandable and is disclosed in a timely manner (IAS 1 - Presentation of Financial Statements, 2020)

In Vietnam, financial statements are prepared in accordance with the Vietnamese Accounting Law together with its guidance circulars issued by the Ministry of Finance, and Vietnamese Accounting Standards (VAS). These regulations are also built based on accounting standards of the International Accounting Standards Board (IASB), but they have not been updated for a long time. Recently, the Ministry of Finance of Vietnam is developing a roadmap to apply international accounting standards, according to which enterprises can apply IFRS/IAS original or apply Vietnamese accounting standards compiled according to from time to time of international accounting standards (VFRS) under Decision 345/QD-BTC dated 16/3/2020 of the Ministry of Finance.

Fraud can be seen as deception, which is an intentional act (Singleton \& Singleton, 2011). The Association of Certified Fraud Examiners (ACFE) defines financial statement fraud as: "the deliberate misrepresentation of the financial position of a business that is accomplished through deliberate misrepresentation or omission of figures or disclosures in financial statements to mislead users of financial statements.

Financial statement fraud is carried out in two directions, either increasing or decreasing assets and profits, in which the main techniques include misrepresentation of time, revenue, liabilities and expenses, misappraisal of assets and misrepresentation (ACFE, 2018). Thus, except in the case of misrepresentation, fraud techniques on financial statements mostly focus on earnings manipulation in one of two ways, over or understatement depending on the purpose of the manipulator.

Earnings manipulation shares many similarities with earnings management and sometimes has ambiguity about the boundaries (Yaping, 2005). Even so, many studies have shown a difference between these two behaviors. Dechow \& Skinner (2000) provides a discriminatory model based on management choice. Earnings manipulation is an accounting policy choice or application that violates accounting principles to distort earnings. Meanwhile, earnings management affects earnings by using accounting principles in a biased way to the extent permitted or using real transactions such as more credit sales to increase revenue. El Diri (2018) compare earnings manipulation and earnings management. He shows that two behaviors are different in concept and method but similar in cause and purpose.
Therefore, studies on earnings manipulation and earnings management can refer back to methods and factors.

The triangle fraud theory states that cheating is only possible when there exist three factors of motivation, opportunity, and rationalization. Financial reporting fraud is mainly a fraud by managers (Manurung \& Hadian, 2013). Rezaee (2005) argues that the motivations for fraudulent financial statements for listed companies are mainly related to economic pressures and incentives related to responding to stock market requirements. The impact of the Covid-19 pandemic on a business' financial and operating issues may prompt managers to commit fraud on financial statements.

Review of financial reporting frauds with related corporate factors

Studies on financial statement fraud and earning management have been carried out in many countries, including Vietnam. The three research streams consist of building fraud-predictive models to evaluate fraud tendency at overall statement level (Beneish, 1999; Dechow et al., 1995; Jones, 1991; Kanapickienè \& Grundiene, 2015; Natalia V. Feruleva, 2017; Ngo Nhat Phuong, 2019; Nguyen Anh \& Pham Thanh, 2015; Pham Thi Bich, 2012; Roychowdhury, 2006); using financial indicators and models to identify fraudulent accounting items on financial statements (Kanapickienè \& Grundienè, 2015; Roxas, 2011); and identifying contextual factors that have a fraud tendency (Bui Van \& Ngo Hoang, 2017; Ghosh et al., 2010; Hoang et al., 2017; Huguet \& Gandía, 2016; Jaggi et al., 2009; Lau, 2020; Nguyen Thi Phuong, 2016; Nguyen Trong, 2015). Basing on the first two streams, the third line of research has achieved plentiful, although some are controversial, outcome. This stream discovered that corporate characteristics (Alzoubi, 2018; Bajra \& Cadez, 2018; Bui Van \& Ngo Hoang, 2017; Huguet \& Gandía, 2016; Lau, 2020; Nguyen Thi Phuong, 2016; Oz \& Yelkenci, 2018; Park \& Shin, 2004; Saadi et al., 2020); audit quality (Alzoubi, 2018; Ghosh et al., 2010; Huguet \& Gandía, 2016; Lau, 2020); and corporate governance characteristics have significant impact on financial reporting fraud tendency (Alzoubi, 2018; Bajra \& Cadez, 2018; Bui Van \& Ngo Hoang, 2017; Carcello et al., 2011; Ghosh et al., 2010; Hoang et al., 2017; Nguyen Thi Phuong, 2016; Nguyen Trong, 2015; Park \& Shin, 2004; Saadi et al., 2020).

The results of studies on corporate characteristics have shown that many factors have an impact on fraud on financial statements, namely:

(1) Firm size: This variable is measured by the logarithm of total assets. Most of the results show that the larger the firm size is, the less earnings management behavior is (Alzoubi, 2018; Bajra \& Cadez, 2018; Bui Van \& Ngo Hoang, 2017; Huguet \& Gandía, 2016; Oz \& Yelkenci, 2018). However, David Lau (2020), Saadi et al. (2020), and Nguyen Thi Phuong (2016) showed a contradict result.

(2) Debt-to-total assets ratio or financial leverage: Most research results show that firms with high debt ratios 
increase earnings management behavior (Huguet \& Gandía, 2016). However, Oz \& Yelkenci (2018), Park \& Shin (2004), Bui Van \& Ngo Hoang (2017), Saadi et al. (2020) showed opposite results. Nevertheless, Nguyen Thi Phuong (2016) showed that financial leverage has no effect on earnings management behavior on financial statements.

(3) Revenue growth rate or total revenue: Huguet \& Gandía (2016) showed that these variables did not affect the behavior that governs income. On the other hand, Oz \& Yelkenci (2018), Park \& Shin (2004) revealed that revenue size has a negative impact on earnings management. More interesting, Saadi et al. (2020) resulted a positive effect

(4) Current solvency: Huguet \& Gandía (2016) indicated that current solvency has no impact on earnings management. However, Nguyen Thi Phuong (2016) resulted a positive correlation between current solvency and earnings management.

(5) The age of the company: Huguet \& Gandía (2016) showed that the older companies are, the less likely they are to practice earnings management. However, Nguyen Thi Phuong (2016) showed that the company age had no impact on earnings management.

(6) Return on assets (ROA): Most studies resulted that return on assets has an inverse relationship with earnings management behavior (Alzoubi, 2018; Bajra \& Cadez, 2018; Bui Van \& Ngo Hoang, 2017; Huguet \& Gandía, 2016). However, Saadi et al. (2020) showed in inverse results.

(7) Negative profit, actual profit over budgeted profit: Huguet \& Gandía (2016) and David Lau (2020) showed that businesses with negative profits increase earnings management behavior.

(8) Net book value over market price: Alzoubi (2018) showed that the higher the ratio of book value to market price, the higher the profit management behavior.

(9) Number of years listed on the stock exchange: Alzoubi (2018) and Nguyen Thi Phuong (2016) showed that the number of years listed on the stock exchange has a negative impact on fraudulent behavior on financial statements.

(10) Operating cash flow or increase in operating cash flow: This variable is measured as the ratio of operating cash flow to total assets or the difference of this year's operating cash flow from the previous year. Most of the research results show that there is no impact of this variable on corporate earnings management behavior (Alzoubi, 2018; Saadi et al., 2020). However, Bajra \& Cadez (2018) indicates that this variable is negatively correlated.

(11) Current assets over sales: David Lau (2020) showed that this variable has a negative impact on corporate earnings management behavior

(12) Return on equity: ROE is negatively correlated with earnings management behavior $(\mathrm{Oz} \&$ Yelkenci, 2018). However, Nguyen Thi Phuong (2016) found a positive effect.

\section{The Beneish model measures fraud on financial} statements

Many models were found to measure financial statement fraud or earnings management behavior, there are models based on regression coefficients to identify abnormal accruals such as (DeAngelo, 1988; Dechow et al., 1995; Jones, 1991; Roychowdhury, 2006). However, these models are computationally complex or have too many variables or are difficult to collect data, so their applicability is limited (Pustylnick, 2012).

Other fraud predictive models using financial ratios (Beneish, 1999; Elam, 1975; Kathleen, A. K., Sterling, T. W. \& Liming, 2004; Keige, 1991; Persons, 1995; Ward \& Foster, 1997) appear to be simpler, easier to collect data, and calculate. In which the M-score model of (Beneish, 1999) is a model used in many studies and shows a high ability to detect fraud on financial statements. Beneish (1999) built a model to measure and evaluate the likelihood of income fraud on financial statements based on a survey of 74 fraud cases detected on the US stock market in the period 1982- 1992. The model of Beneish (1999) calculates the Mscore according to the following formula:

Mscore $(8$ variables $)=-4,84+0,92 *$ DSRI + $0,528 * \mathrm{GMI}+0,404 * \mathrm{AQI}+0,892 * \mathrm{SGI}+0,115 * \mathrm{DEPI}-$ $0,172 *$ SGAI $+4,679 *$ TATA $-0,327 *$ LVGI

In which, the variables used include:

- DSRI: Days Sales in Receivables Index.

- GMI: Gross Profit Index

- AQI: Asset Quality Index

- SGI: Sales gGrowth index

- DEPI: Depreciation Index

- SGAI: Selling and Administrative Expenses Index

- $\quad$ LVGI: Leverage Index

- $\quad$ TATA: Total Accruals to Total aAssets

Beneish (1999) is also interested in the relationship between detectability and cost, thereby investigating different classification thresholds. The higher the threshold, the more likely it is to detect the correct fraudulent business, but the more likely to detect the wrong business that is not cheating. For example, if you choose the threshold of -1.49 , the probability of correctly detecting fraudulent businesses is $58 \%$ and the probability of detecting false businesses is $7.6 \%$. If the threshold is -1.78 , the figures are $74 \%$ and $13.8 \%$, respectively.

The model of Beneish (1999) has been tested in many countries and found to be effective in detecting fraud in financial statements. Research results in Indonesia by (Tarjo \& Herawati, 2015) on the basis of 35 companies with fraud and 35 companies without fraud show that the ability to correctly identify fraud is $77.1 \%$ and not fraud is $80 \%$ with a classification threshold of -2.22 . Similarly, Özcan's study (2018) on 87 fraudulent companies and 87 non-cheat companies in Turkey gave an overall prediction accuracy of $85.63 \%$, with a threshold of -1.78. Shabnam Fazli Aghghaleh et al. (2016) use the model of Beneish (1999) and Dechow et 
al. (2011) to investigate fraud on financial statements of companies listed on the Malaysian stock market for the period 2001-2014. both models are effective with average accuracy of $73.17 \%$ and $76.22 \%$ respectively (threshold is -2.22) in predicting both fraud and non-fraud cases. Some recent studies in Vietnam have used the Beneish model (1999) to assess the likelihood of fraud on financial statements (Chi et al., 2021; Huu Anh \& Ha Linh, 2016)

Roxas (2011) is interested in revenue fraud. This author uses the model of Beneish (1999) and compares it with an earlier model of Beneish (1997). The Beneish model (1997) calculates Mscore from 5 variables, compared with the Beneish model (1999) reduces 3 variables: SGAI, LVGI and TATA; As follows:

Msocre $(5$ variables $)=-6.065+0.823 *$ DSRI +0.906 $* \mathrm{GMI}+0.593 * \mathrm{AQI}+0.717 * \mathrm{SGI}+0.107 * \mathrm{DEPI}$.

With a sample of 93 cases of fraud on financial statements of revenue, the research results of Roxas (2011) show that if the threshold of 2.76 is applied to the 5-variable model and compares with the threshold of 2.22 of the 8 -variable model, the research results of Roxas (2011) show that variable, the 5-variable model enhances the ability to detect fraud more. Specifically, the fraud detection rate of the 5 -variable model is $62 \%$ compared with $46 \%$ of the 8 -variable model. Some recent studies show the effectiveness of the 5-variable model in Russia (Tkachenko et al., 2020; Vetoshkina et al., 2020). Nwoye et al. (2015) conducted a comparative study of 28 -variable and 5-variable models in Nigeria, showing that the 5-variable model can effectively predict the existing risk of material misstatement as well as promising potential. ability to reduce Type II errors, although the 8 -variable model is likely to reveal more than the underlying risk in the financial statements.

\subsection{Hypothesis development}

The Covid-19 pandemic caused many difficulties for the economy, including listed companies. The agency theories, the signal theory and the fraud triangle allow to predict the likelihood of managers performing fraud on the financial statements. The likelihood of cheating depends on many different factors from previous studies.

The objective of this study was to examine the effect of the epidemic situation on the likelihood of fraud on financial statements and the relationship with other factors.

\section{Impact of the pandemic}

The pandemic reduced revenue and increased costs as the market was impacted by supply and production chain disruptions. Managers are under pressure from shareholders, so they can perform fraudulent tricks on financial statements to hide the true business situation. Research by Hay et al. (2020) summarizes the results of surveys of government organizations on the challenges of the post-pandemic audit profession including the assumption of going concern, internal control and fraud. Research hypothesis \#1: Covid 19 increases fraudulent behavior on corporate financial statements.
The influence of business characteristics

Fraudulent behavior or manipulation of profits on financial statements as described in the above section depends on the following characteristics of the business: Growth, operating cash flow, size, financial leverage, ability return on assets, solvency, age of the business.

Research hypothesis 2: The above characteristics of enterprises have an influence on fraudulent behavior on financial statements.

Interaction effects between business characteristics and the pandemic

A pandemic is an event that affects the entire business of a business that can, therefore, interact with business characteristics in influencing fraudulent behavior on financial statements.

Research Hypothesis 3: There is an interaction in the effects of the pandemic and corporate characteristics on fraudulent financial reporting.

\section{RESEARCH METHOD}

\subsection{Research model and variables}

This research model will examine the impact of the pandemic and some corporate characteristics on fraudulent behavior on financial statements (Figure 1). Independent variables related to firm characteristics are selected from previous studies, including growth, operating cash flow, size, financial leverage, ROA, solvency, age. of the enterprise. The scale of variables is presented in Table 1.

Table 1. Scale of variables

\begin{tabular}{|c|l|c|l|}
\hline No & \multicolumn{1}{|c|}{ Variable } & Abb & \multicolumn{1}{|c|}{ Scale } \\
\hline 1 & $\begin{array}{l}\text { Financial } \\
\text { statement fraud }\end{array}$ & Msocre & $\begin{array}{l}\{0 ; 1\} \text { Fraud = 1, } \\
\text { non-fraud =0 }\end{array}$ \\
\hline 2 & COVID 19 & COVID & $\begin{array}{l}\{0 ; 1\} \text { Covid-19= } \\
1 ; \\
\text { non-Covid-19=0 }\end{array}$ \\
\hline 4 & $\begin{array}{l}\text { Operating } \\
\text { cashflow }\end{array}$ & GROW & $\begin{array}{l}\text { Revenue t } \\
\text { Revenue t-1) } \\
\text { Revenue } t-1\end{array}$ \\
\hline 5 & Corporate size & FSIZE & $\begin{array}{l}\text { Operating } \\
\text { cashflow / Total } \\
\text { asset }\end{array}$ \\
\hline 6 & $\begin{array}{l}\text { Financial } \\
\text { leverage }\end{array}$ & LEVE & $\begin{array}{l}\text { Liability/Total } \\
\text { asset }\end{array}$ \\
\hline
\end{tabular}

(Souce: Author, 2021)

\subsection{Data}

Research data is collected from DataStream for information on financial statements of corporates listed on Vietnam stock markets from 2014 to 2020. Missing or faulty data will be excluded from the sample. The final study sample number was 2831 samples. The research sample is shared at the link: https://drive.google.com/file/d/1HfoPS 8D2sOC7cd3sl h06u6uJ3kbLmbZ/view?usp=sharing 
Statistical tests will be performed using $\mathrm{R}$ software, with T-tests, test for model selection and logit regression.

\section{RESEARCH FINDINGS}

\subsection{Descriptive statistics}

The statistical results presented in Table 2 show that:

- The sample size is 2831. The total number of fraudulent and non-fraudulent cases are 1439 and 1392 respectively, indicating that there is a balance in the sample (Table $2 \mathrm{a}$ and Table $2 \mathrm{~b}$ ).

Table 2a. Descriptive statistics

\begin{tabular}{|c|c|c|c|c|c|}
\hline & vars n & mean & \multicolumn{2}{|c|}{ sd skew kurtosis } & se \\
\hline YEAR & 12831 & 2017.36 & $1.71-0.20$ & -0.92 & 0.03 \\
\hline FIRMx & 22831 & 291.63 & $171.24 \quad 0.01$ & -1.24 & 3.22 \\
\hline$X^{*}$ & 32831 & 1416.00 & $817.38 \quad 0.00$ & -1.20 & 15.36 \\
\hline LEVE & 42831 & 0.48 & $0.22-0.15$ & -0.82 & 0.00 \\
\hline ESIZE & 52831 & 27.51 & 1.560 .40 & 0.28 & 0.03 \\
\hline $\mathrm{CP}$ & 62831 & 0.05 & $0.14 \quad 0.01$ & 6.48 & 0.00 \\
\hline GRON & 72831 & 1.00 & 38.4152 .70 & 2791.38 & 0.72 \\
\hline ROA & 82831 & 0.06 & $0.07 \quad 1.20$ & 9.10 & 0.00 \\
\hline FA & 92831 & 13.96 & $4.09 \quad 0.78$ & 2.49 & 0.08 \\
\hline LIQ & 102831 & 3.05 & 7.6011 .46 & 173.44 & 0.14 \\
\hline COVID & 112831 & 0.30 & $0.46 \quad 0.85$ & -1.28 & 0.01 \\
\hline Mscore. 5 & 122831 & 014269.60 & $6357.44 \quad 53.15$ & 2823.95 & 276.16 \\
\hline Mscore.5.01 & 132831 & 0.51 & $0.50-0.03$ & -2.00 & 0.01 \\
\hline
\end{tabular}

(Souce: Author, 2021)

Table $\mathbf{2 b}$. The year-on-year case of fraud

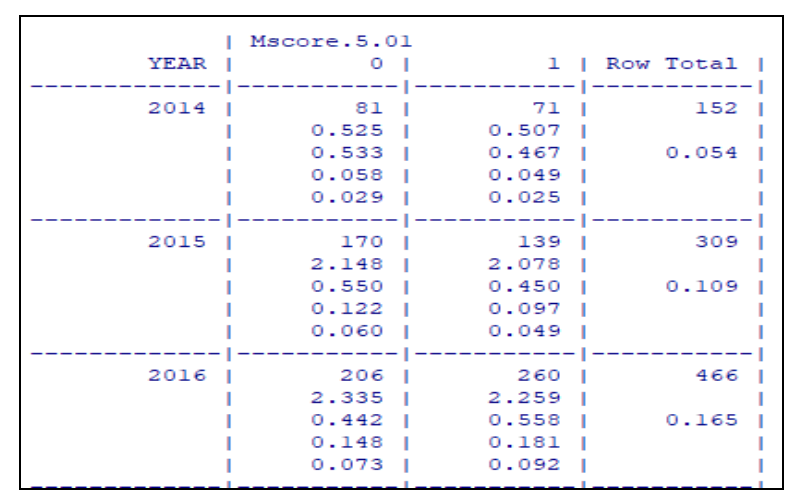

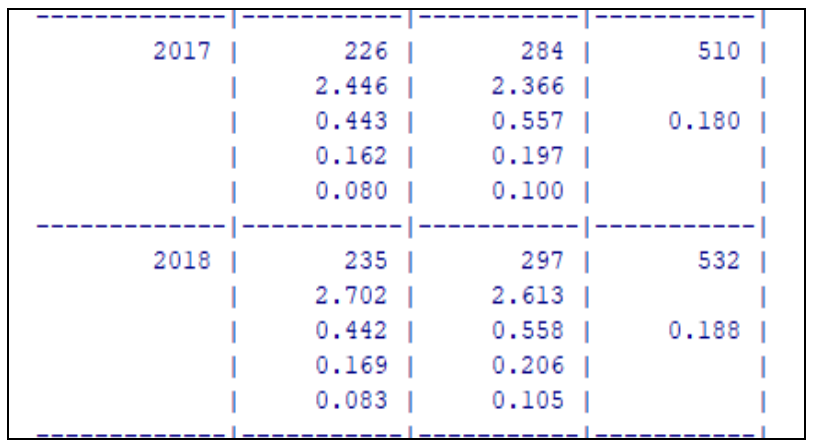

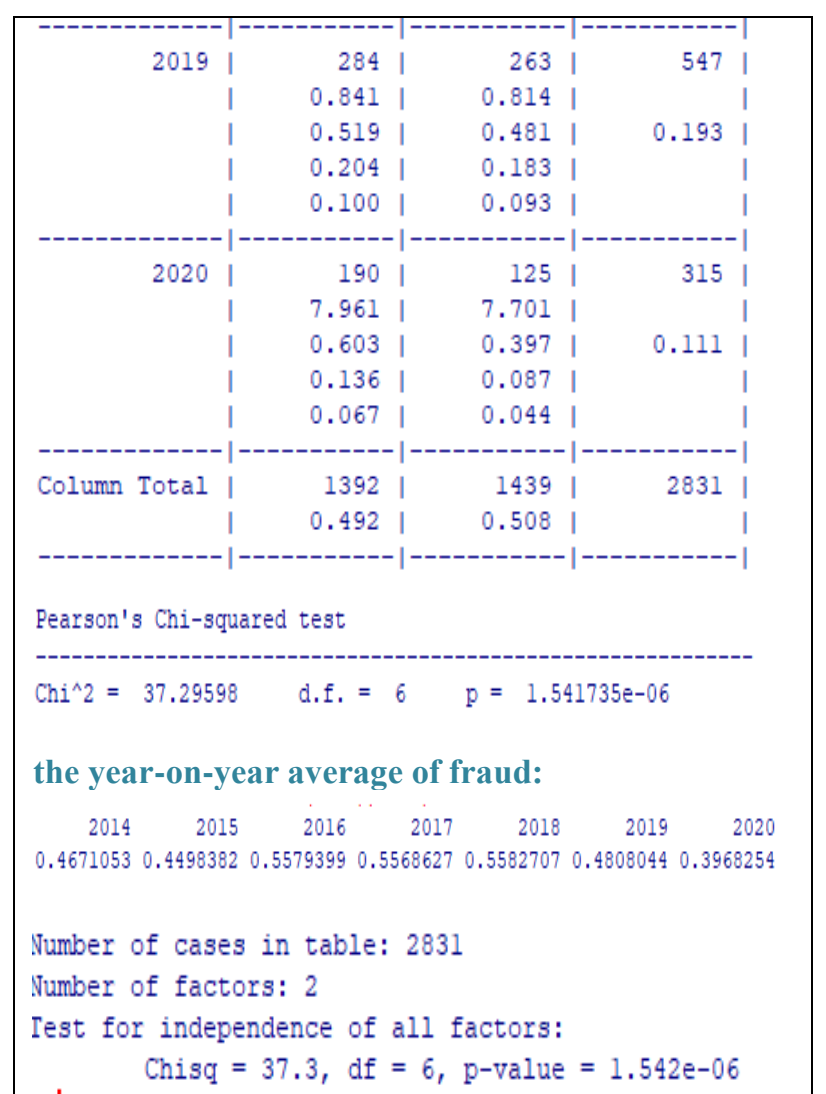

(Souce: Author, 2021)

The number of fraudulent cases in 2018 was the highest (297 cases) and 2014 was the least ( 71 cases). And the year-to-year fraud difference is statistically significant ( $p=1.541735 \mathrm{e}-06$ ) indicating that the events of the year can affect fraud on the financial statements. Likewise, the year-on-year average of fraud shows that 2016, 2017, 2018 have the highest average fraud and 2020 have the lowest average fraud, and this difference is statistically significant ( $p$ -value $=1.542 \mathrm{e}-06)$ (The results are shown in Table 2b).

According to the results in Table 2c, the total number of enterprises cheating during Covid 19 and non-Covid 19 period was 388 and 1051 enterprises respectively, this difference is statistically significant $(\mathrm{p}=4.179387 \mathrm{e}-05)$. The mean of Fraud on the Report Count (referred to as fraud) of the Covid 19 and non-Covid 19 samples was 0.450 versus 0.533 and this difference was statistically significant ( $\mathrm{p}$-value $=4.117 \mathrm{e}-05)$.

- $\quad$ The average operating cash flow under the Covid 19 and non-Covid 19 samples was 0.058 and 0.049 , respectively, but this difference was not statistically significant $(p$-value $=0.1011)$. Similarly, the mean of the growth variable in the Covid 19 and non-Covid 19 samples is 0.128 and 1.377 , respectively, and this difference is also not statistically significant ( $\mathrm{p}$-value $=0.2294)$. (The results are presented in Table 2e). 
Table 2c. Descriptive statistics: Covid vs. non-Covid sample

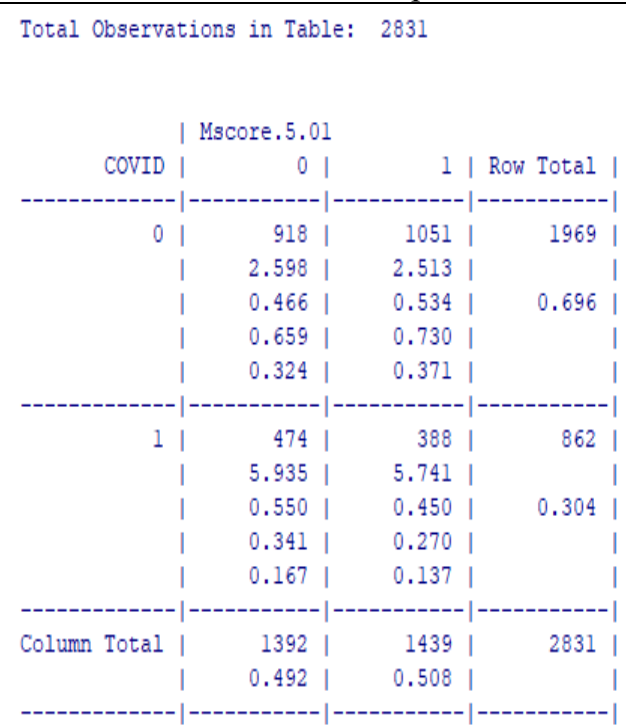

Statistics for All Table Factors

Pearson's Chi-squared test

$\mathrm{Chi}^{\wedge} 2=16.78813 \quad$ d.f. $=1 \quad \mathrm{p}=4.179387 \mathrm{e}-05$

Pearson's Chi-squared test with Yates' continuity correction $\mathrm{Chi}_{2}=16.45508$ d.f. $=1 \quad p=4.981656 \mathrm{e}-05$

The mean of Fraud on the Report Count of the Covid 19:

$\begin{array}{cr}0 & 1 \\ 0.5337735 & 0.4501160\end{array}$

Welch Two Sample t-test

data: Mscore. 5.01 by COVID

$\mathrm{t}=4.1119, \mathrm{df}=1645.8, \mathrm{p}$-value $=4.117 \mathrm{e}-05$

alternative hypothesis: true difference in means between group 0 and group 1 is

95 percent confidence interval:

0.043752480 .12356248

sample estimates:

mean in group 0 mean in group 1

$0.5337735 \quad 0.4501160$

(Souce: Author, 2021)

Besides, the results of the correlation test (Table 2d) show that fraudulent behavior has a negative correlation with the Covid variable, cash flow, and the age of the business, which has a positive correlation with the variable of financial leverage. main. And this table of results also shows that COVID 19 has a positive relationship with the size of the company and the age of the business; has a negative correlation with fraud on financial statements and profitability; Covid 19 has no correlation with business cash flow, growth, and solvency
Table 2d. Correlation matrix

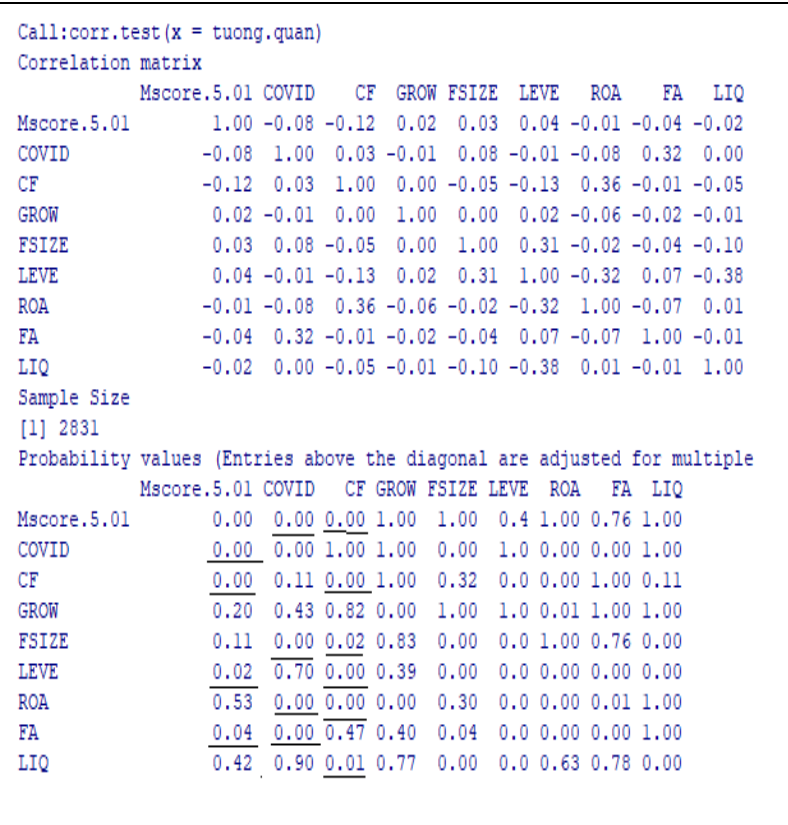

(Souce: Author, 2021)

In summary, it can be statistically concluded that Covid-19 is related to fraudulent behavior on financial statements. However, Covid 19 has no correlation with operating cash flow of the business as well as the increase in financial statements. head of the business.

Table 2e. T-test on operating cashflow and growth The average operating cash flow under the Covid 19

$\begin{array}{rr}0 & 1 \\ 0.04905847 & 0.05834677\end{array}$

$$
\text { Welch Two Sample t-test }
$$

data: CF by COVID

$t=-1.6403, d f=1716.4, p$-value $=0.101$

alternative hypothesis: true difference in means between group 0 and group 1

95 percent confidence interval:

$-0.020394704 \quad 0.001818095$

sample estimates:

mean in group 0 mean in groun 1

0.04905847

The average operating cash flow under the Covid 19:

0
1.37726780 .1285793
Nelch Two Sample t-test
data: GRow by covid
$t=1.2022$, df $=1975$, p-value $=0.2294$
alternative hypothesis: true difference in means between group 0 and group 1
95 percent confidence interval:
-0.7882671 3.2856443
sample estimates:
mean in group 0 mean in group 1
$1.3772678 \quad 0.1285793$

(Souce: Author, 2021) 


\subsection{Regression result of Research model 1}

Research model 1 examines the influence of Covid 19, and the characteristics of enterprises on fraud on financial statements. Research Model 2 examines the interactive impact of Covid 19 with business growth and operating cash flow on fraudulent behavior on financial statements.

The regression results of the F-test $(p$-value $=0.1436)$ in Table 3 show that the data in the model have no difference in the intercept and slope between enterprises and over time. In other words, the pooled data are suitable for performing the tests.

Table 3. F-test to select model

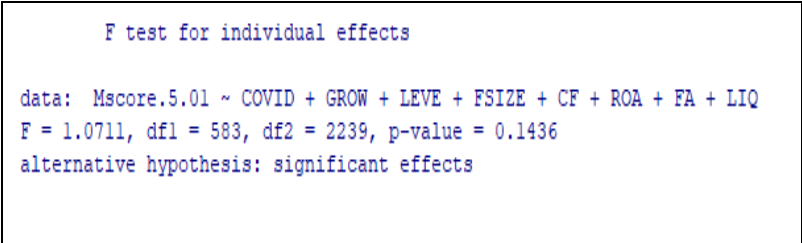

(Souce: Author, 2021)

The logit regression results of model 1 presented in Table 4 show that the Covid variable, the growth and the operating cash flow of the business have an impact on the fraudulent behavior on the financial statements at the level of significance $5 \%$ And $1 \%$. The other variables have no effect. The test results show that the regression coefficients are non-zero (pseudo- $\mathrm{r}^{2}=4.836402 \mathrm{e}-02$ ). Specifically:

- Covid 19 reduces the fraudulent behavior of businesses at $5 \%$ significance level, the regression coefficient and $\mathrm{P}$ value are -0.247080 and 0.00582 , respectively, which means that during the Covid 19 period, businesses reduce their behavior. more fraud than in the years before Covid 19. This is contrary to the original hypothesis. However, this result is also easily understandable. Through descriptive statistics, up to now, the growth of the business as well as its operating cash flow has not been affected by Covid 19 and businesses expect that investors will understand the impact of the epidemic. disease will not react negatively in the market, so businesses are less likely to commit fraud than before.

Table 4. Logit regression for Model 1

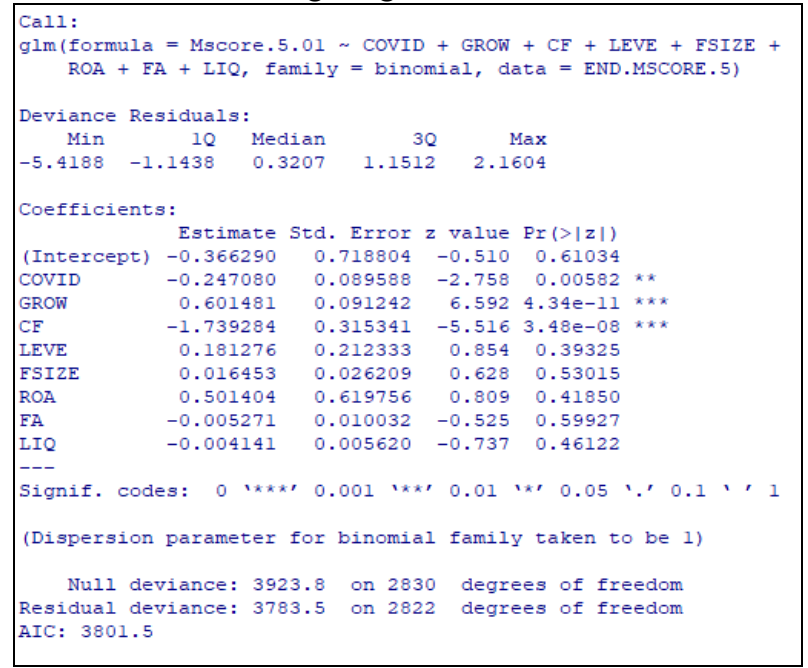

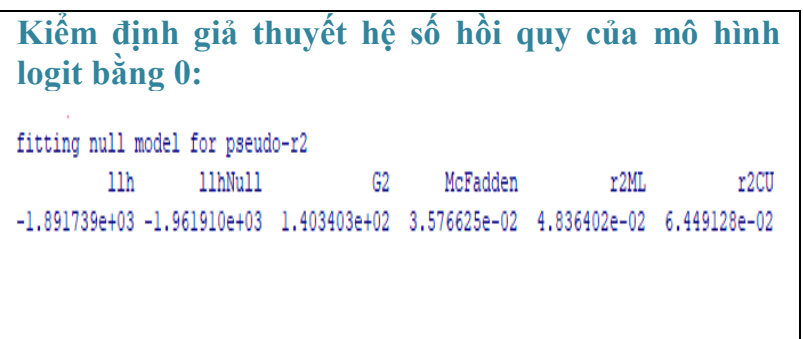

(Souce: Author, 2021)

- Firm growth has a positive effect on fraud at the $1 \%$ significance level, the regression coefficient and $\mathrm{P}$ value are 0.601481 and $4.34 \mathrm{e}-11$, respectively. This result is consistent with the original hypothesis, which means that the larger the business, the more fraud is performed. The results of this study are similar to the results of the 2020 study by author Farqad Mohammed Bakr Al Saadi et al., while the studies before 2020 mostly showed no impact.

- Operating cash flow of the business has a negative impact on fraud at $1 \%$ significance level, the regression coefficient and p-value are: -1.739284 and $4.48 \mathrm{e}-08$, respectively. This means that businesses with positive operating cash flow are less likely to commit fraud. This is consistent with the study by Bajra \& Cadez (2018) although some other studies suggest no effect.

- Although it is not for forecasting purposes, the sensitivity test results show that the model has the correct predictability at $58.8 \%$ and the sensitivity of the model is $59.7 \%$.

Table 4. (Cont) - Logit regression for Model 1 


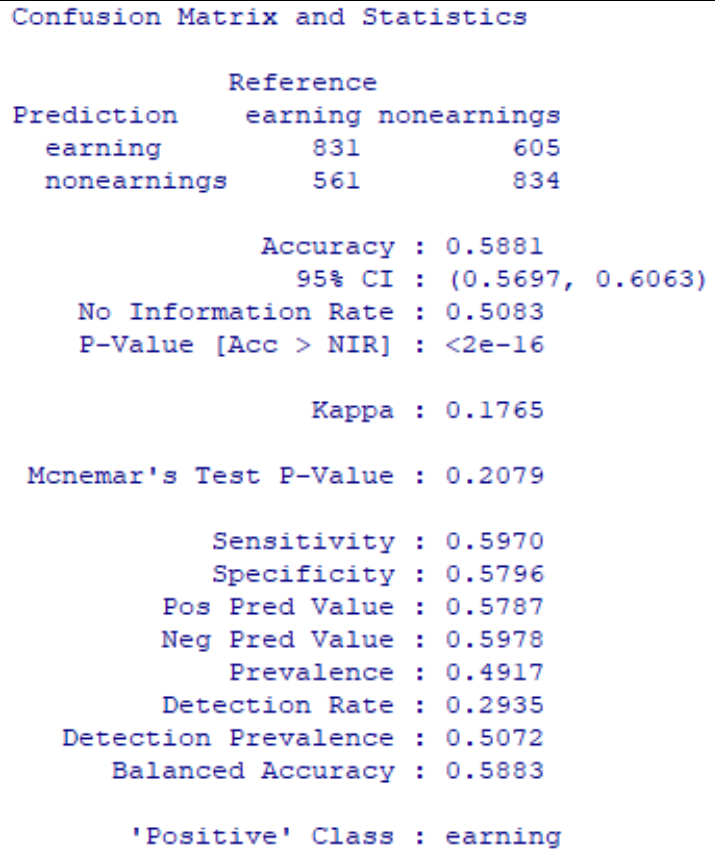

Multi-colinear test:

$\begin{array}{lllllll}\text { COVID GRON } & \text { CP } & \text { LEVE } & \text { FSI2E } & \text { ROA } & \text { FA } & \text { LIQ }\end{array}$ $1.1479561 .036714 \quad 1.191043 \quad 1.492570 \quad 1.139531 \quad 1.3580041 .1337551 .1993399$

Variance test:

\section{Goldfeld-Quandt test}

data: $\operatorname{logit}$

$G Q=1.0037$, df $1=1407$, df2 $=1406$, p-value $=0.4723$

alternative hypothesis: variance increases from segment 1 to 2

(Souce: Author, 2021)

Thus, the regression results of model 1 show that Covid 19 , operating cash flow and operating cash flow growth of the business, have an impact on fraud on the financial statements. Whether operating cash flow and business growth in the context of Covid 19 have an impact on fraud on financial statements. To better understand the impact of these two variables with the interaction of Covid 19 variable, the study will implement the second research model (M2) as follows:

Msocre $=\beta 0+\beta 1 \mathrm{COVID}+\beta 2 \mathrm{GROW}+\beta 3 \mathrm{CF}+$ $\beta 4$ COVID.GROW $+\beta 5$ COVI.CF (M2)

\subsection{Regression result of Research model 2}

The logit regression results of model 2 presented in Table 5 show that the growth variable with the interaction of the Covid 19 variable has no effect on cheating behavior ( $p$-value $=0.29298$ ). This means that high-growth businesses don't cheat more due to the pandemic.
Table 5. Logit regression for Model 2

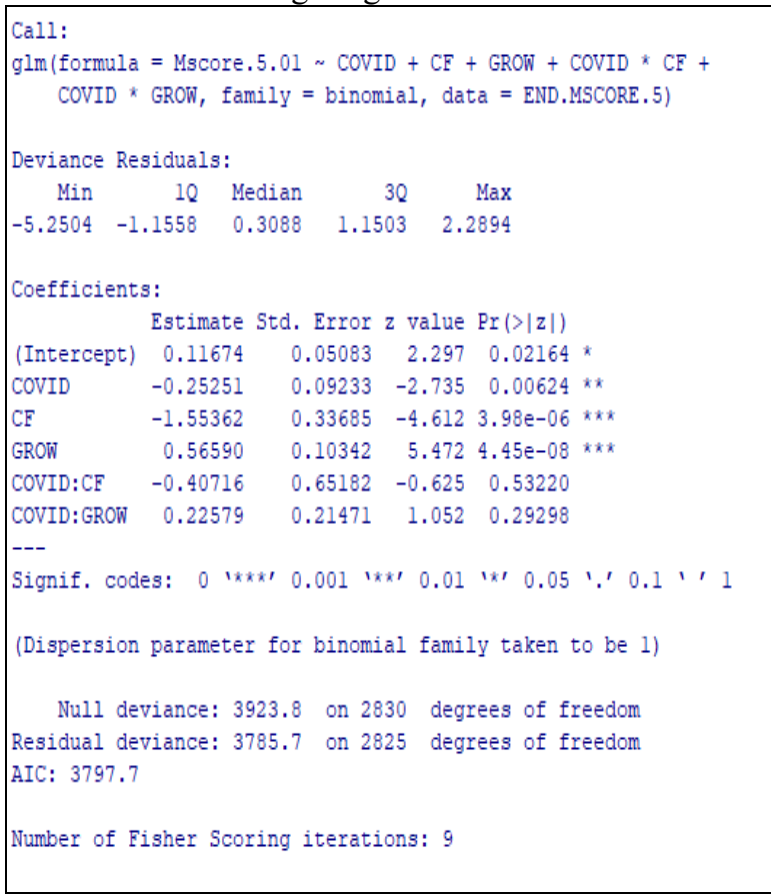

(Souce: Author, 2021)

Similarly, the logit regression results of model 2 presented in Table 5 show that the operating cash flow variable of the enterprise with the interaction of the Covid 19 variable has no effect on fraudulent behavior (p-value $=0.53220)$ and as such, businesses with low operating cash flow are more likely to commit fraud not due to the impact of the pandemic.

The results of study 1 and study 2 show that: during the pandemic, businesses are less likely to commit fraud, including high-growth, negative cash-flow businesses. tend to perform fraudulent acts, they also do not commit fraudulent acts during the Covid period.

\section{CONCLUSION}

Previous studies have tested the impact of factors of business characteristics on fraudulent behavior on financial statements. However, the context of the Covid 19 pandemic is a new point for this study to examine the impact of the pandemic on fraudulent behavior on the financial statements of managers in this context.

Previous studies in Vietnam have all measured fraudulent behavior on financial statements or earnings drivers according to Jones model (1991) and adjusted Jones model (1995). These models do not have a cutoff point, making it difficult to identify fraudulent financial statements. In this study, the variable of cheating behavior is measured by the 5-variable Mscore model of Beneish (1997) adjusted by $M$. Roxas (2011) to overcome these shortcomings while emphasizing the possibility of fraudulent acts related to revenue.

Two logit regression models were performed to measure the impact of Covid variable, growth variable, cash flow as well as four control variables namely firm size, financial leverage, ROA and age of the business, as well 
as the interaction variables between Covid and growth and operating cash flow to fraudulent behavior on financial statements.

Research results show that, until 2020, the relationship between the Covid-19 pandemic situation and operating cash flow as well as business growth has not been statistically significant. The growth and operating cash flow of a business have an impact on fraudulent financial reporting, but this has no relation to the pandemic situation.

\section{REFERENCES}

[1]. Ahmed, A. S., \& Safdar, I. (2018). Dissecting stock price momentum using financial statement analysis. Accounting and Finance, 58, 3-43. https://doi.org/10.1111/acfi.12358

[2]. Alzoubi, E. S. S. (2018). Audit quality, debt financing, and earnings management: Evidence from Jordan. Journal of International Accounting, Auditing and Taxation, 30, 69-84. https://doi.org/10.1016/j.intaccaudtax.2017.12. 001

[3]. Archived: WHO Timeline - COVID-19. (2021). https://www.who.int/news/item/27-04-2020-wh o-timeline---covid-19

[4]. Bajra, U., \& Cadez, S. (2018). The Impact of Corporate Governance Quality on Earnings Management: Evidence from European Companies Cross-listed in the US. Australian Accounting Review, 28(2), 152-166. https://doi.org/10.1111/auar.12176

[5]. Beneish, M. D. (1999). The Detection of Earnings Manipulation. Financial Analysts Journal, 55(5), 24-36. https://doi.org/10.2469/faj.v55.n5.2296

[6]. Bui Van, D., \& Ngo Hoang, D. (2017). Board characteristics and profit management behavior of companies listed on the Vietnamese stock market. Journal of Science (Open University), 12(2).

[7]. Carcello, J. V., Hollingsworth, C. W., Klein, A., \& Neal, T. L. (2011). Audit Committee Financial Expertise, Competing Corporate Governance Mechanisms, and Earnings Management. SSRN Electronic Journal, February. https://doi.org/10.2139/ssrn.887512

[8]. Chi, B. P., Thuy, N. T. H., \& Huong, L. T. M. (2021). Predicting Listed Firms' Financial Statement Fraud Risk in the Vietnamese Securities Market. VNU Journal of Science: Economics and Business; Vol 37 No 1. https://doi.org/10.25073/2588-1108/vnueab.44 94

[9]. DeAngelo, L. E. (1988). Managerial competition, information costs, and corporate governance: The use of accounting performance measures in proxy contests. Journal of Accounting and Economics, 10(1), 3-36.

https://doi.org/https://doi.org/10.1016/0165-41
01(88)90021-3

[10]. Dechow, P. M., Ge, W., Larson, C. R., \& Sloan, R. G. (2011). Predicting material accounting misstatements. Contemporary Accounting Research, 28(1), 17-82.

[11]. Dechow, P. M., \& Skinner, D. J. (2000). Earnings management: Reconciling the views of accounting academics, practitioners, and regulators. Accounting Horizons, 14(2), 235250. https://doi.org/10.2308/acch.2000.14.2.235

[12]. Dechow, P. M., Sloan, R. G., \& Sweeney, A. P. (1995). Detecting Earnings Management. The Accounting Review, 70(2), 193-225. http://www.jstor.org/stable/248303

[13]. El Diri, M. (2018). Introduction to Earnings Management. Springer.

[14]. Elam, R. (1975). The effect of lease data on the predictive ability of financial ratios. The Accounting Review, 50(1), 25-43.

[15]. Ghosh, A., Marra, A., \& Moon, D. (2010). Corporate Boards, Audit Committees, and Earnings Management: Pre- and Post-SOX Evidence. Journal of Business Finance and Accounting, 37(9-10), 1145-1176. https://doi.org/10.1111/j.1468-5957.2010.0221 8. $\mathrm{x}$

[16]. Goodell, J. W. (2020). COVID-19 and finance: Agendas for future research. Finance Research Letters, 35(March). https://doi.org/10.1016/j.frl.2020.101512

[17]. Hay, D., Shires, K., \& Van Dyk, D. (2020). Auditing in the time of COVID - the impact of COVID-19 on auditing in New Zealand and subsequent reforms. Pacific Accounting Review, $33(2)$, $179-188$ https://doi.org/10.1108/PAR-09-2020-0155

[18]. Hoang, T. C., Abeysekera, I., \& Ma, S. (2017). The Effect of Board Diversity on Earnings Quality: An Empirical Study of Listed Firms in Vietnam. Australian Accounting Review, 27(2), 146-163. https://doi.org/10.1111/auar.12128

[19]. Huguet, D., \& Gandía, J. L. (2016). Audit and earnings management in Spanish SMEs. $B R Q$ Business Research Quarterly, 19(3), 171-187. https://doi.org/10.1016/j.brq.2015.12.001

[20]. Huu Anh, N., \& Ha Linh, N. (2016). Using the M-score Model in Detecting Earnings Management: Evidence from Non-Financial Vietnamese Listed Companies. VNU Journal of Science: Economics and Business, 32(2), 1423.

[21]. IAS 1 - Presentation of financial statements, (2020).

[22]. Jaggi, B., Leung, S., \& Gul, F. (2009). Family control, board independence and earnings management: Evidence based on Hong Kong firms. Journal of Accounting and Public Policy, 28(4), 281-300. https://doi.org/10.1016/j.jaccpubpol.2009.06.0 
02

[23]. Jensen, M. C., \& Meckling, W. H. (1976). Theory of the firm: Managerial behavior, agency costs and ownership structure. Journal of Financial Economics, 3(4), 305-360. https://doi.org/https://doi.org/10.1016/0304-40 $5 \mathrm{X}(76) 90026-\mathrm{X}$

[24]. Jones, J. J. (1991). Earnings Management During Import Relief Investigations. Journal of Accounting Research, 29(2), 193-228. https://doi.org/10.2307/2491047

[25]. Kanapickienė, R., \& Grundienè, Ž. (2015). The Model of Fraud Detection in Financial Statements by Means of Financial Ratios. Procedia - Social and Behavioral Sciences, 213, 321-327. https://doi.org/10.1016/j.sbspro.2015.11.545

[26]. Kathleen, A. K., Sterling, T. W. \& Liming, G. (2004). Can financial ratios detect fraudulent financial reporting? In Managerial Auditing Journal (Vol. 19, Issue 1, pp. 15-28). https://doi.org/10.1108/02686900410509802

[27]. Keige, P. N. (1991). Business failure prediction using discriminant analysis.

[28]. Lau, D. (2020). The Effect of Audit Quality on the Quality of Management Earnings Forecasts: Evidence from Japan. Academy of Accounting and Financial Studies Journal, 24(4), 1-17.

[29]. Littler, C. R. (2006). A signalling theory of strategy. Academy of Management 2006 Annual Meeting: Knowledge, Action and the Public Concern, AOM 2006, 1-7. https://doi.org/10.5465/ambpp.2006.22896822

[30]. Manurung, D. T., \& Hadian, N. (2013). Detection Fraud of Financial Statement with Fraud Triangle. Proceedings of 23rd International Business Research Conference, 978-1.

[31]. MOIT. (2021). The Covid-19 epidemic has had a negative impact on trade and service activities.

https://moit.gov.vn/tin-tuc/thi-truong-trong-nuo c/dich-covid-19-tac-dong-tieu-cuc-den-hoat-do ng-thuong-mai-dic.html

[32]. Natalia V. Feruleva, M. A. S. (2017). Detecting Financial Statements Fraud: the Evidence from Russia. Journal of Corporate Finance Research / Kорпоративные Финансы | ISSN: 2073-0438, 11(2), 32-45. https://doi.org/10.17323/j.jcfr.2073-0438.11.2. 2017.32-45

[33]. Ngo Nhat Phuong, D. (2019). Aggregate factors representing corporate governance impact on profit management behavior of listed manufacturing companies in Vietnam. University of Economics Ho Chi Minh city.

[34]. Nguyen Anh, H., \& Pham Thanh, T. (2015). Testing and identifying model for earnings management behavior of the listed companies in Vietnam. Science and Technology
Development, 18, 7-17.

[35]. Nguyen Thi Phuong, H. (2016). Factors affecting the quality of financial statements of listed companies on the stock market-Experimental evidence in Vietnam. University of Economics Ho Chi Minh city.

[36]. Nguyen Trong, N. (2015). Impact of corporate governance on information quality of financial statements in listed companies in Vietnam. University of Economics Ho Chi Minh city.

[37]. Nwoye, U., Obiorah, J., \& Chukwunonso, E. (2015). Assessing the Risk of Fraud in Published IFRS and Nigerian GAAP Financial Reports: A Comparative Application of the Beneish Models. The IUP Journal of Accounting Research \& Audit Practices, 1, 2142.

[38]. Oz, I. O., \& Yelkenci, T. (2018). Examination of real and accrual earnings management: A cross-country analysis of legal origin under IFRS. International Review of Financial Analysis, 58(July 2017), 24-37. https://doi.org/10.1016/j.irfa.2018.04.003

[39]. Ozili, Peterson and Arun, T. (2020). Prepare for the coronavirus global recession. SSRN Electronic Journal, 99850, 1-28. https://mpra.ub.uni-muenchen.de/99850/

[40]. Park, Y. W., \& Shin, H. H. (2004). Board composition and earnings management in Canada. Journal of Corporate Finance, 10(3), 431-457. https://doi.org/10.1016/S0929-1199(03)000257

[41]. Persons, O. S. (1995). Using Financial Statement Data to Identify FFS. In Journal of Applied Business Research (Vol. 11, Issue 3, pp. 38-46).

[42]. Pham Thi Bich, V. (2012). Identification model to adjust profits of companies listed on the Ho Chi Minh Stock Exchange. JABES, 258, 35-42.

[43]. Pustylnick, I. (2012). an Algorithm for the Detection of Revenue and Retained Earnings Manipulation. Accounting \& Taxation, 4(2), 95-105.

http://search.proquest.com/docview/124247919 0 ? accountid $=12212$

[44]. Rababah, A., Al-Haddad, L., Sial, M. S., Chunmei, Z., \& Cherian, J. (2020). Analyzing the effects of COVID-19 pandemic on the financial performance of Chinese listed companies. Journal of Public Affairs, 20(4). https://doi.org/10.1002/pa.2440

[45]. Rezaee, Z. (2005). Causes, consequences, and deterence of financial statement fraud. Critical Perspectives on Accounting, 16(3), 277-298. https://doi.org/10.1016/S1045-2354(03)000728

[46]. Roxas, M. (2011). Financial Statement Fraud Detection Using Ratio and Digital Analysis. 
Journal of Leadership, Accountability, and Ethics, 8, 56-66.

[47]. Roychowdhury, S. (2006). Earnings management through real activities manipulation. Journal of Accounting and Economics, 42(3), 335-370. https://doi.org/10.1016/j.jacceco.2006.01.002

[48]. Saadi, F. M. B. Al, Hasan, H. F., \& Khalbas, H. N. (2020). Relationship between Characteristics of the Board Directors and Earning Management: Case Study in the Iraq Stock Exchange. Al-Kut University College Journal, 5(2), 87-106. https://www.iasj.net/iasj/article/187735

[49]. Shabnam Fazli Aghghaleh, Zakiah Muhammaddun Mohamed, \& Mohd Mohid Rahmat. (2016). Detecting Financial Statement Frauds in Malaysia: Comparing the Abilities of Beneish and Dechow Models. Asian Journal of Accounting and Governance, 7, 57-65.

[50]. Singleton, T. W., \& Singleton, A. J. (2011). Fraud Auditing and Forensic Accounting, Fourth Edition. In Fraud Auditing and Forensic Accounting, Fourth Edition (Fourth). John Wiley \& Sons, Inc. https://doi.org/10.1002/9781118269183

[51]. Spence, A. (1973). Job Market Signaling. The Quarterly Journal of Economics, 87(3), 355374.

https://econpapers.repec.org/RePEc:oup:qjecon :v:87:y:1973:i:3:p:355-374.

[52]. Tarjo, \& Herawati, N. (2015). Application of Beneish M-Score Models and Data Mining to Detect Financial Fraud. Procedia - Social and Behavioral Sciences, 211(September), 924-930. https://doi.org/10.1016/j.sbspro.2015.11.122

[53]. Tkachenko, L., Andrey, E., Pozdeeva, G., \& Romanyuk, V. (2020). Modern approaches of detecting financial statement fraud. SHS Web of Conferences, $\quad 80, \quad 01024$. https://doi.org/10.1051/shsconf/20208001024

[54]. Vetoshkina, E., Cherepanova, P., Semenikhina, N., \& Tukhvatullin, R. (2020). Financial Statements Fraud Detection: Analysis of Beneish and Roxas Models Applicability (Russian Approach). Helix, 10(5), 212-217. https://doi.org/10.29042/2020-10-5-212-217

[55]. Ward, T. J., \& Foster, B. P. (1997). A note on selecting a response measure for financial distress. Journal of Business Finance and Accounting, 24(6), 869-879. https://doi.org/10.1111/1468-5957.00138

[56]. Yaping, N. (2005). The Theoretical Framework of Earnings Management. Canadian Social Science, 1(3), 32-38. 